\title{
The long way home
}

We discovered a slow distress seeping out of our

reconciled years — from freezing, and melting,

and freezing, it had cracked the compass rose.

Now we almost always choose the long way home,

circling the airport perimeter road to stay gone -

and circling again this afternoon, we draw

the winter solstice down from fretted high clouds

rusted pink, the only petals left unscattered.

The windshield's vellum frost lets thawed soft

islands of distance disclose, to the west,

the world's white nest scraped flat for safe flight -

to the east, tangled centuries of willow scratch

and dwarf black spruce shanks out of true -

valiant small gestures hobbled in knots of dry snow.

Due south, beyond reach, cold heaven's seventh

blue half-life bows over the river's jumble ice -

a curtainless window, its glaciated sill. At home

in the moment, we might have called it a day.

Angel to cobalt, we bend with the evening north.

The Northern Review 46 | 2017 